\title{
Boron dynamics related to fruit growth and seed production in kiwifruit (Actinidia deliciosa, cv. Hayward)
}

\author{
Carlos Sotomayor ${ }^{1}$, Paulina Norambuena ${ }^{1}$, and Rafael Ruiz ${ }^{2}$ \\ 'Pontificia Universidad Católica de Chile, Facultad de Agronomía e Ingeniería Forestal. Casilla 306-22. \\ Santiago, Chile. \\ ${ }^{2}$ Instituto de Investigaciones Agropecuarias. CRI La Platina. Casilla 439-3. Santiago, Chile.
}

\begin{abstract}
C. Sotomayor, P. Norambuena, and R. Ruiz. 2010. Boron dynamics related to fruit growth and seed production in kiwifruit (Actinidia deliciosa, cv. Hayward). Cien. Inv. Agr. 37(1):133141. The effect of foliar boron treatments on fruit growth and seed development in Actinidia deliciosa, cv. Hayward, was studied. The distal leaves (BH) or flowers (BF) of a shoot were sprayed with $500 \mathrm{mg} \mathrm{L}^{-1}$ boric acid during the flowering period. The mobility of boron from the leaves to the flowers through the phloem was determined by spraying only the leaves. From 0 to $96 \mathrm{~h}$ after treatment, leaves and flowers were sampled and total boron was assessed. At harvest time, fruit weight and diameter plus seed weight and number were measured for the different treatments. The weight of fruits growing from shoots with boron-treated leaves were $14.1 \%$ higher than the control, while the weight of fruits derived from boron-treated flowers was $17 \%$ higher than that of fruits from untreated flowers. Regarding fruit length, significant differences between boron treatments and the control were observed, with an $8.2 \%$ and $8.5 \%$ increase for $\mathrm{BH}$ and BF treatments, respectively. No significant differences were found in fruit diameter. Fruits grown from shoots with boron-treated leaves had $43 \%$ more seeds than fruit grown from untreated control shoots, while fruits resulting from boron-treated flowers had $44 \%$ more seeds. This demonstrates the positive effect of boron treatment in seed production. No differences were observed in seed weight between treatments. The correlation coefficient between seed number and fruit weight was $\mathrm{r}^{2}=0.1294$ for $\mathrm{BF}, \mathrm{r}^{2}=0.1298$ for $\mathrm{BH}$ and $\mathrm{r}^{2}=0.0002$ for the control. There was no variation in non-treated leaves and flowers with respect to boron concentration for a 96 $\mathrm{h}$ time period. On the contrary, in sprayed leaves boron levels reached up to $16 \mathrm{mg} \mathrm{kg}^{-1}$ between 24 and $48 \mathrm{~h}$ and slightly decreased after $96 \mathrm{~h}$, demonstrating the boron absorption capacity of leaves. In the flowers from the shoots with boron-treated leaves, there was a significant $14 \mathrm{mg} \mathrm{kg}^{-1}$ increase in boron concentration from 24 to $96 \mathrm{~h}$, showing boron mobility from leaves to flowers.
\end{abstract}

Key words: Boric acid, boron, fruit weight, kiwifruit, seed number, seed weight.

\section{Introduction}

Kiwifruit (Actinidia deliciosa var. deliciosa (A.Chev) C.F.Liang et A.R. Ferguson) is a func-

Received 14 May 2009. Accepted 14 July 2009.

Corresponding author: csotomas@uc.cl tionally dioecious plant which requires a cultivar with pistillate flowers (e.g., Hayward) and another cultivar with staminate flowers (e.g., Matua) to produce fruit. Optimal production can only be achieved if the conditions for pollination and fruit development are favorable (Tromp et al., 2005).

The staminate flowers of kiwifruit produce numerous pollen grains which insects transport to 
the stigmas of pistillate flowers. Pistillate flowers have numerous ovules $(>1,000$ ovules per flower), each one corresponding to a potential seed. Vasilakakis et al. (1997) found that the presence of a high number of seeds is required to sustain the large kiwifruit cv. Hayward and determined a correlation $(r=0.816)$ between the number of seeds and fruit weight. Other authors, as Bellini et al. (1989), Hopping (1990), Intoppa and Piazza (1990), Lawes and Woolley (1990), Testolin et al. (1991) and Valenzuela and Konig (1991), have also found a high correlation between fruit weight and the number and weight of seeds, demonstrating that the Hayward kiwifruit needs more than 1,000 seeds to reach a weight greater than $100 \mathrm{~g}$.

For about 80 years, boron has been known to be an essential element for the growth of higher plants; however, its biochemical function is still unknown (Bolanos et al., 2004). A series of physiological processes have been studied where boron is essential, such as processes associated with plant reproduction and basic flowering and fruiting (Blevins and Lukaszewski, 1998). The most recent studies attribute the essential processes of structural conservation of cell walls, functional conservation of cell membranes and the support of metabolic activities specific to boron (Bolanos et al., 2004).

Flower tissues have relatively higher boron content than vegetative tissues. Although the pollen grains of most species are naturally low in boron, the styles, stigmas and ovaries generally have higher concentrations, according to Blevins and Lukaszewski (1998). According to Dell and Huang (1997), low boron levels in flowers reduce fertility by damaging pollen formation and affecting the growth of the pollen tube. Low boron levels can also have post-insemination effects that affect embryogenesis, leading to seed abortion and fruit malformation.

In vascular plants, boron moves passively from the roots to the leaves and shoots via transpiration (Husa and McIlrath, 1965). Once in the leaves, boron is, in general, restricted to the apoplast (Sattelmacher, 2001). Therefore, boron is considered to be relatively immobile in the dicotyledonous phloem, and a continuous sup- ply is required to achieve normal plant growth (Brown and $\mathrm{Hu}, 1998$ ). However, in plants where a portion of the photoassimilates is translocated in the phloem as sugars-alcohols, boron is transported freely from mature organs to growing tissues (Liakopoulos et al., 2005). In the Malus, Pyrus and Prunus species, it has been found that boron mobility is due to the formation of stable complexes with sorbitol. In species that do not produce large amounts of polyols (e.g., walnut), once boron has entered the leaves via transpiration, it does not undergo secondary transportation to the phloem but remains immobilized and accrues in the leaves (Brown and $\mathrm{Hu}, 1998$; Brown and Shelp, 1997).

A few authors (Nyomora et al., 2000; Wojcik and Wojcik, 2003) have found an improvement in productivity from fruit trees treated with foliar applications of boron. According to Hanson et al. (1985), in 'Italian' plum trees and in 'D'Anjou' pear trees, the increase in foliar concentration of boron by pre-anthesis applications have led to a significant improvement of fruiting or fruit setting. In addition, fruiting and productivity in almond trees have been significantly increased with foliar applications of boron (Nyomora et al., 2000; Nyomora and Brown, 1999; Sotomayor and Castro, 1997; Nyomora and Brown, 1997; Hanson, 1991).

The mobility of boron has not been determined in Actinidia. Papadakis et al. (2004), in a study of boron toxicity in fruit plants, mentioned that orange trees and kiwifruit are species where boron may have restricted phloematic mobility. On the other hand, Sotiropoulos et al. (2004) stated that the presence of high concentrations of boron in mature leaves in comparison to young leaves is evidence of boron immobility in the phloem of kiwifruit. In this context, Sotiropoulos et al. (2006) studied boron distribution in kiwifruit, and found that the decrease of this element from the basal part to the apical part could be attributed to low boron mobility in the plant, although they also found that the boron content is not uniform in kiwifruit.

Although sucrose is the main sugar that is translocated in A. deliciosa, Bieleski et al. (1997) determined that this plant genus contains an 
unusually high inositol level, reaching $20 \%$ of the total soluble carbohydrates in the leaves. In addition, Klages et al. (2004) found that mioinositol represents between 10 and $20 \%$ of the soluble carbohydrates in the mature leaves of A. deliciosa, cv. Hayward. Together, this data points to the possibility that mio-inositol may permit boron mobility via a simplistic route, where sugar alcohols form complexes with boric acid. Thus, boron accrues in the meristematic zones in A. deliciosa fruits.

Currently, the growth of Hayward kiwifruit requires the development of technology to increase productivity and, specifically, fruit size, an important quality factor that is fundamental for its commercialization (Calvanese, 2008; Sotomayor, 1996).

Therefore, the objective of this work was to study boron mobility in kiwifruits, cv. Hayward. We determined whether boron is displaced from leaves to fruits and determined the effect of foliar and flower boron applications on fruit weight and their capacity to produce seeds.

\section{Materials and methods}

During the 2006-2007 season, two parallel experiments were carried out in a 20 -year-old kiwifruit, cv. Hayward, orchard located in Nogales, V Region of Chile (32 $\left.44^{\prime} 06^{\prime \prime} \mathrm{S}, 71^{\circ} 14^{\prime} 12^{\prime \prime} \mathrm{W}\right)$. The planting used pollinating plants of the cvs. Matua and Tomuri, at a proportion of 5\% each. Pollination was carried out with 20 beehives per hectare during the flowering season. The productivity of the orchard was $20 \mathrm{tha}^{-1}$, which is near the average for Hayward kiwifruit production in Chile. The soil is of alluvial origin, loam, deep and with good drainage. The irrigation was carried out by micro-spraying with well water.

In January, foliar boron concentration in this orchard was 30 to $40 \mathrm{mg} \mathrm{kg}^{-1}$ of total boron, and soil boron concentration was $1 \mathrm{mg} \mathrm{kg}^{-1}$. Both values are considered appropriate, according to international standards (Clark et al., 1986; Beutel et al., 1994). The experimental unit was composed of specific mixed shoots, with four flowers (further fruits) in the basal portion and four to six leaves in the distal or apical portion of the shoot, separated by 20 to $40 \mathrm{~cm}$ from the flowers (distal leaves).

\section{Effect of boron on kiwifruit fruiting (Experiment 1)}

The effect of $0.5 \mathrm{~g} \mathrm{~L}^{-1}$ boric acid $\left(\mathrm{H}_{3} \mathrm{BO}_{3}\right)$ was studied. Boric acid was sprayed on leaves or flowers from the same shoot during kiwifruit fruiting. The applications were made during the period of flower opening (November 1, 2006). An experimental design of random blocks was used, with nine replications. Three specific mixed shoots from each plant were selected (experimental units), with four flowers and at least four distal leaves each. The following treatments were considered: a) BF: Spraying of $0.5 \mathrm{~g} \mathrm{~L}^{-1}$ boric acid on individual flowers of the mixed shoot; b) BH: Spraying of $0.5 \mathrm{~g} \mathrm{~L}^{-1}$ boric acid on distal leaves of the mixed shoot; and c) T: control, without boron application (only water).

The fruits were harvested on March 6, 2007, and the individual weight and diameter of fruits (polar and equatorial), number of seeds and seed weight were measured. The data obtained for each parameter were processed by an analysis of variance, using the program SAS 2008 (SAS Institute Inc., Cary, NC, USA). In cases where significant differences appeared, the treatments were compared by their means, by Tukey Kramer's procedure $(p \leq 0.05)$. The correlation between the number of seeds (as an independent variable) and the respective weight of the fruit (as a dependent variable) was estimated separately, according to the treatments.

\section{Boron dynamics on kiwifruit (Experiment 2)}

Boron mobility between distal leaves sprayed with $500 \mathrm{mg} \mathrm{L}^{-1}$ boric acid and the flowers of the same shoot was studied. According to a randomized block design with six replications, five homogeneous and healthy kiwifruit plants, cv. Hayward, were selected. Four specific mixed shoots were marked in each plant, with four 
flowers and at least four distal leaves. On November 5, 2006, the distal leaves were sprayed with boric acid, when they were at $50 \%$ of opening. Leaves were sprayed only with water in the control group.

A sampling of treated leaves and flowers at 0 , 24, 48 and $96 \mathrm{~h}$ after the application was taken. Analyses of these samples were made in the Laboratory of Foliar and Soil Analysis, Pontificia Universidad Católica de Chile. The samples were washed, ground and dried, with a further calcination at $500^{\circ} \mathrm{C}$ in presence of calcium oxide and further digestion with hydrochloric acid. The measurement of total boron was done using a colorimetric method based on azomethine (Walinga et al., 1995).

An analysis of variance and the Tukey Kramer test were performed with the data obtained. Then, orthogonal contrasts between treatments. Then, orthogonal contrasts between treatments and control were carried out.

\section{Results and discussion}

Effect of boron on kiwifruit fruiting (Experiment 1)

Weight. The highest weights corresponded to fruits whose distal leaves or flowers had been sprayed with boric acid during the anthesis period, while the control fruits (without boron application) reached a significantly lower weight. Significant differences were not observed in fruit weight between the treatment with boron to the flowers (BF) and boron to the leaves (BH), but both were different in comparison to the control, with an increase of 17.3 and $14.1 \%$, respectively (Table 1).
This result indicates that the exogenous application of boron may improve kiwifruit fruiting, which agrees with the data on plum trees (Hanson et al., 1985), almond trees (Nyomora et al., 2000), pear trees (Wojcik and Wojcik, 2003) and avocados (Jaganath and Lovatt, 1995).

Fruit diameter. With respect to the longitudinal diameter of fruits, significant differences were observed between the treatments and the control, with an increase in diameter of 8.2 and $8.5 \%$ in relation to the control, for the $\mathrm{BF}$ and $\mathrm{BH}$ treatments, respectively. On the other hand, the equatorial diameter did not reveal a statistical difference between treatments and control (Table 1).

Sotomayor (1996) stated that the equatorial diameter should not increase beyond a certain limit, because the 'Hayward' kiwifruit fruit must maintain a certain length/width ratio. Thus, fruits with a 1.28 ratio are considered appropriate or normal, while a ratio lower than 1.20 represents a fruit that is too wide. From a commercial point of view, a ratio of 1.24 is considered optimal. Therefore, the values obtained in this experiment can be considered appropriate for the fruits from all treatments (Table 1).

Number of seeds. The fruits subjected to boron treatment produced a higher number of seeds in comparison to the control, and the BF treatment obtained the highest figure $(\mathrm{p} \leq 0.05)$. The $\mathrm{BF}$ and $\mathrm{BH}$ treatments did not show a significant difference compared to each other, and led to an increase in the number of seeds, in relation to the control group, of 44 and $43 \%$, respectively.

The results obtained confirm the positive correlation between the number of seeds and kiwifruit weight, as mentioned in previous works (Hopping, 1990; Lawes and Woolley, 1990). The higher the number of seeds, the higher the fruit weight will be. The results obtained agree 
Table 1. Effect of boron treatments in the final fruit weight, lengthwise diameter, equatorial diameter, seed number and individual seed weight of kiwifruit (Actinidia deliciosa, cv. Hayward) fruits.

\begin{tabular}{|c|c|c|c|c|c|c|c|}
\hline Treatments & $\begin{array}{l}\text { Average } \\
\text { weight } \\
\mathrm{g}\end{array}$ & $\begin{array}{l}\text { Weight } \\
\text { increment } \\
\%\end{array}$ & $\begin{array}{l}\text { Lengthwise } \\
\text { diameter } \\
\mathrm{mm}\end{array}$ & $\begin{array}{l}\text { Equatorial } \\
\text { diameter } \\
\mathrm{mm}\end{array}$ & $\begin{array}{l}\text { Length } \\
\text { /wide } \\
\text { relationship }\end{array}$ & $\begin{array}{l}\text { Seed } \\
/ \text { fruit } \\
\text { no. }\end{array}$ & $\begin{array}{l}\text { Seed } \\
\text { weight } \\
\text { mg }\end{array}$ \\
\hline $\begin{array}{l}\text { BF: } 0.5 \mathrm{~g} \mathrm{~L}^{-1} \text { of boric acid } \\
\text { sprayed on flowers }\end{array}$ & $85.97 \mathrm{a}^{1}$ & 17.3 & $65.54 \mathrm{a}^{1}$ & $51.90 \mathrm{~ns}$ & 1.26 & $894.47 \mathrm{a}^{1}$ & $1.46 \mathrm{~ns}$ \\
\hline $\begin{array}{l}\text { BH: } 0.5 \mathrm{~g} \mathrm{~L}^{-1} \text { of boric acid } \\
\text { sprayed on distal leaves }\end{array}$ & $83.60 \mathrm{a}$ & 14.1 & $65.72^{\mathrm{a}}$ & $51.09 \mathrm{~ns}$ & 1.29 & $891.5 \mathrm{a}$ & $1.47 \mathrm{~ns}$ \\
\hline $\begin{array}{l}\text { T: control without boric acid } \\
\text { spraying }\end{array}$ & $73.26 \mathrm{~b}$ & - & $60.53 b$ & $49.31 \mathrm{~ns}$ & 1.23 & $621.5 \mathrm{~b}$ & $1.44 \mathrm{~ns}$ \\
\hline
\end{tabular}

with studies by Lovatt and Dugger (1984), Nyomora et al. (2000), Loomis and Durst (1992) and Lovatt (1999), which showed that boron plays a role in pollen germination and the further development of the pollen tube, allowing for an increased amount of fertilized ovules and more seeds per fruit.

Seed weight. Significant differences were not observed in the individual weight of seeds between the treatments with boron in comparison to the control (Table 1). From these results, it can be deduced that boron application did not have an effect on seed size; thus, this parameter does not influence the final weight of the fruits.

Fruit weight /Number of seeds ratio. The correlation between variables was $\mathrm{r}^{2}=0.1294$ for $\mathrm{BF}, \mathrm{r}^{2}$ $=0.1298$ for $\mathrm{BH}$ and $\mathrm{r}^{2}=0.0002$ for the control. While the correlation is relatively weak in the treatments with boron, it is positive and differs from the control which is practically null. The results obtained confirm the positive correlation existing between the number of seeds and the kiwifruit fruit weight, as mentioned in previous works (Hopping, 1990; Lawes and Woolley, 1990).

\section{Boron dynamics in kiwifruit (Experiment 2)}

The results of the chemical analysis of leaves with and without application of boric acid are shown in Table 2, before the application and after 24,48 and $96 \mathrm{~h}$.

In leaves without boron application or in the control (Table 2), there were no significant differences in the concentration of total boron between 24 and $96 \mathrm{~h}$. On the contrary, in leaves where boron was applied, the boron concentration increased significantly $24 \mathrm{~h}$ after the application and was still increased at $96 \mathrm{~h}$.

Table 2. Total boron concentration in kiwifruit (Actinidia deliciosa, cv. Hayward) leaves treated with boric acid, at four time points.

\begin{tabular}{lccc}
\hline & \multicolumn{3}{c}{ Foliar total boron concentration $\left(\mathrm{mg} \mathrm{kg}^{-1}\right)$ determined at } \\
\hline Treatments & $0 \mathrm{~h}$ & $24 \mathrm{~h}$ & $48 \mathrm{~h}$ \\
Control leaves & $48.4 \mathrm{~ns}$ & $49.8 \mathrm{~ns}$ & $49.2 \mathrm{~ns}$ \\
Treated leaves & 48.0 & 64.0 & 67.0 \\
Significance & $48.0 \mathrm{a}^{1}$ & & $61.2 \mathrm{~b}^{1}$ (average of 24,48 and $\left.96 \mathrm{~h}\right)$ \\
\hline${ }^{1}$ Means followed by different letters indicate that the orthogonal contrast is highly significant $(\mathrm{p} \leq 0.0001) . \mathrm{ns}=$ non significant.
\end{tabular}


This result shows that boric acid was absorbed by the leaves and rapidly increased in concentration, and that this concentration was maintained for at least $96 \mathrm{~h}$. Foliar boron may then begin to be exported mainly to the fruits and the shoot, normalizing the foliar boron level. In addition, this agrees with Klages et al. (1998), who indicated the possibility that mio-inositol is transported through the phloem from the leaves to the fruits.

In shoot flowers whose leaves did not receive boron application (control), the concentration of boron did not vary at $96 \mathrm{~h}$ (Table 3 ). On the contrary, in flowers with leaves subject to boron application, the level of boron increased significantly to $14 \mathrm{mg} \mathrm{kg}^{-1}$ at $24 \mathrm{~h}$ and maintained this accumulation during the 4 days of the test. This shows that boron applied on distal leaves from the same shoot was able to translocate rapidly (24 h) to the flowers (sinks) and be maintained at a concentration higher than normal for $96 \mathrm{~h}$. Thus, it can be deduced that the favorable effect of boron application may occur in the leaves and result in the production of a higher number of seeds.

Brown and $\mathrm{Hu}$ demonstrated in 1998 that boron applied by the foliar route may translocate to growing organs in species where the element is mobile. The main factor conferring mobility to boron in the phloem is the synthesis of sugar-alcohols and the subsequent transportation of B-poliol complexes. On the other hand, Bieleski et al. (1997) mentioned that Actinidia plants contain unusually high levels of inositol, and Klages et al. (2004) indicated the possibility that this sugar might be transported by the phloem from the leaves to the fruits, forming B-inositol complexes that may allow boron mobility. Therefore, boron may accrue in the meristematic zones in fruits of $A$. deliciosa.

When the average number of seeds in fruits from boron treatment applied on distal leaves of the shoots (BH) was analyzed, it was observed that the treatment increased the number of seeds by $43 \%$. This may be interpreted as an effect of boron translocation from the distal leaves to the flowers, leading to a subsequent higher number of seeds. This would demonstrate that boron presents a certain phloematic mobility in kiwifruit, according to the conditions of this experiment. This result contrasts with studies by Papadakis et al. (2004) and by Sotiropoulos et al. (2004), which found an immobility of boron in the phloem of kiwifruit shoots.

Table 3. Total boron concentration of kiwifruit (Actinidia deliciosa, cv. Hayward) flowers grown in shoots bearing boron-treated leaves, at four time points.

\begin{tabular}{lcccc}
\hline & \multicolumn{3}{c}{ Flower total boron concentration $\left(\mathrm{mg} \mathrm{kg}^{-1}\right)$ determined at } \\
\hline Treatments & $0 \mathrm{~h}$ & $24 \mathrm{~h}$ & $48 \mathrm{~h}$ & $96 \mathrm{~h}$ \\
Control flowers & $38.0 \mathrm{~ns}$ & $38.2 \mathrm{~ns}$ & $39.0 \mathrm{~ns}$ & $38.2 \mathrm{~ns}$ \\
Flowers grown in shoots & & & & \\
with boron treated leaves & 39.0 & 53.0 & 52.0 & 50.5 \\
Significance & $39.0 \mathrm{a}^{1}$ & $51.8 \mathrm{~b}^{1}$ (average of 24,48 and $\left.96 \mathrm{~h}\right)$ \\
\hline
\end{tabular}

${ }^{1}$ Means followed by different letters indicate that the orthogonal contrast is highly significant $(\mathrm{p} \leq 0.0001)$. $\mathrm{ns}=$ non significant. 


\section{Resumen}

\section{Sotomayor, P. Norambuena y R. Ruiz. 2010. Dinámica del boro en relación con el crecimiento del fruto y la producción de semillas en kiwi (Actinidia deliciosa, cv. Hayward).} Cien. Inv. Agr. 37(1):133-141. Se estudió el efecto de aplicaciones foliares de ácido bórico $0.5 \mathrm{~g}$ $\mathrm{L}^{-1}$ sobre el crecimiento del fruto de kiwi (Actinidia deliciosa), cv. Hayward y el desarrollo de semillas. Las aplicaciones fueron realizadas sobre hojas distales de brotes $(\mathrm{BH})$ o sobre flores (BF). Se buscó también establecer la movilidad del boro desde hojas a flores con aplicaciones realizadas solamente sobre hojas distales de brotes florales. Entre 0 y 96 hs post-aplicación se realizaron análisis químicos tanto en hojas como flores, con y sin tratamiento foliar, para determinar boro total. En la cosecha se midió peso y diámetro de frutos y número y peso de semillas según tratamiento. El peso de frutos del tratamiento BH superó significativamente al testigo en $14,1 \%$, en tanto los del tratamiento $\mathrm{BF}$ alcanzaron un $17,3 \%$ más. Los tratamientos BF y BH aumentaron significativamente el diámetro de frutos en un 8,2 y $8,5 \%$, respecto del testigo. No se encontraron diferencias estadísticas entre tratamientos respecto a diámetro ecuatorial. Los frutos del tratamiento BH produjeron $43 \%$ más semillas que el testigo, mientras que los del tratamiento BF las incrementaron en $44 \%$, ambos aumentos significativos. Esto indicaría el efecto favorable del boro aplicado en la producción de semillas. No hubo diferencias entre tratamientos en peso individual de semillas. La correlación entre número de semillas y peso del fruto respectivo fue de $\mathrm{r}^{2}=0,1294$ para $\mathrm{BF}, \mathrm{r}^{2}=0,1298$ para $\mathrm{BH}$ y $\mathrm{r}^{2}=0,0002$ para el testigo. En las hojas sin aplicación de boro (testigos), durante 96 horas, no hubo variaciones en la concentración de boro total, tanto en hojas como en flores. En las hojas tratadas, el nivel de boro subió significativamente en $16 \mathrm{mg} \mathrm{kg}^{-1}$ después de $24 \mathrm{~h}$, manteniéndose así hasta 48 horas. En cuanto al boro aplicado en hojas distales, y medido en las flores del mismo brote, el nivel subió significativamente en $14 \mathrm{mg} \mathrm{kg}^{-1}$ a las $24 \mathrm{~h}$ y hasta las $96 \mathrm{~h}$. Esto demostraría la eventual movilidad floemática del boro entre hojas y flores.

Palabras clave: Acido bórico, boro, kiwi, número de semillas, peso de semillas, peso de frutos.

\section{References}

Bellini, E., P. Mazzone, N. Pilone and A. Rotundo. 1989. Il ruolo delle api nell impollinazione dell Actinidia. Informatore Agrario 45:46-52.

Beutel, J., K. Uriu, J. Post, and J. Pearson. 1994. Nutrition and Fertilization. Pages 58-60. In: Hasey, J., Johnson, R., Grant, J. and W. Reil (eds.). Kiwifruit Growing and Handling. University of California Division of Agriculture and Natural
Resources. California, USA.

Bieleski, R., C. Clark, and K. Klages. 1997. Identification of myo-inositol as a major carbohydrate in kiwifruit, Actinidia deliciosa. Phytochemistry 46:51-55.

Blevins, D., and M. Lukaszewski. 1998. Boron in plant structure and function. Annu. Rev. Plant Physiol. Plant Mol. Biol. 49:481-500.

Bolanos, L., K. Lukaszewski, J. Bonilla, and D. Blevins. 2004. Why boron? Plant Physiol. Bio- 
chem. 42:907-912

Brown, P., and H. Hu. 1998. Boron mobility and consequent management in different crops. Better Crops 82:28-30.

Brown, P., and B. Shelp. 1997. Boron mobility in plants. Plant and Soil 193:85-101.

Calvanese, M. 2008. Oportunidades y desafíos del mercado asiático para el kiwi chileno. Seminario de Kiwis ASOEX. $2^{\circ}$ Ciclo. Octubre 2008. Santiago de Chile.

Clark, J., P. Holland, and G. Smith. 1986. Chemical composition of bleeding sap from kiwifruit vines. Annals of Botany 58:353-362.

Dell, B., and L. Huang. 1997. Physiological response of plants to low boron. Plant and Soil. 193:103120.

Hanson, E., M. Chaplin, and P. Breen. 1985. Movement of foliar applied boron out of leaves and accumulation in flower buds and flower parts of Italian prune. HortScience 20:747-748.

Hanson, E. 1991. Movement of boron out of tree fruit leaves. HortScience 26:271-273.

Hopping, M. 1990. Floral biology, pollination and fruit set. Pages 71-96. In: I.J. Warrington and G.C.Weston (eds.). Kiwifruit, Science and Management. The New Zealand Society for Horticultural Science.Ray Richards Publ., Auckland, New Zealand.

Husa, J., and W. McIlrath. 1965. Absorption and translocation of boron by sunflower plants. Botan. Gaz. 126:186-194.

Intoppa, F., and M. Piazza. 1990. Impollinazione dell'actinidia: quattro anni di esperienze. Informatore Agrario 18:45-52.

Klages, K., H. Boldingh, J.Cooney, and E. MacRae. 2004. Planteose is a short term storage carbohydrate in Actinidia leaves. Functional Plant Biology 31:1205-1214.

Lawes, G., and D. Woolley. 1990. Seeds and other factors affecting fruit size in kiwifruit. Acta Hoticulturae 282:257-264.

Liakopoulos, G., S. Stavrianakou, M. Filippou, C. Fasseas, C. Tsadilas, I. Drossopoulo, and G. Karabourniotis. 2005. Boron remobilization at low boron supply in olive in relation to leaf and phloem mannitol concentrations. Tree Physiol. 25:157-165.

Loomis, W., and R. Durst. 1992. Chemistry and biol- ogy of boron. Bio-Factors 3:229-239.

Lovatt, C. 1999. Management of foliar fertilization. Terra 17:257-264.

Lovatt, C. and W.Dugger, 1984. Boron. Pages 389421. In: E. Frieden (ed.). Biochemistry of the Essential Ultratrace Elements. Plenum Pub. Corp., N.York. USA.

Nyomora, A., and P. Brown. 1997. Fall foliar applied boron increases tissue boron concentration and nut set of almond. J. Amer. Soc. Hort. Sci. 122:405-410.

Nyomora, A., and P. Brown. 1999. Rate and time of boron application increase almond productivity and tissue boron concentration. HortScience 34:242-245.

Nyomora, A., P. Brown, K. Pinney, and V. Polito. 2000. Foliar application of boron to almond trees affects pollen quality. J. Amer. Soc. Hort. Sci. 125:265-270.

Papadakis, I., K.N. Dimassi, A.M. Bosabalidis, I.N. Therios, A. Patakas, and A. Giannakoula. 2004. Effects of B excess on some physiological and anatomical parameters of 'Navelina' orange plants grafted on two rootstocks. Environmental and Experimental Botany 51:247-257.

Sattelmacher, B. 2001. The apoplast and its significance for plant mineral nutrition. New Phytologist 149:167-192.

Sotiropoulos, T., I. Therios, and K. Dimassi. 2004. Uptake of boron by kiwifruit plants under various levels of shading and salinity. Journal of Plant Nutrition 27:1979-1989.

Sotiropoulos, T., I. Therios, and K. Dimassi. 2006. Seasonal accumulation and distribution of nutrient elements in fruit of kiwifruit vines affected by boron toxicity. Australian Journal of Experimental Agriculture 46:1639-1644.

Sotomayor, C. 1996. Efectividad del CPPU y de otros reguladores del crecimiento en el desarrollo de frutos de kiwi. Ciencia e Investigación Agraria 23:12-16.

Sotomayor, C., and J. Castro. 1997. The influence of boron and zinc sprays at bloomtime on almond fruit set. Acta Horticulturae 470:402-405.

Testolin, R., G. Vizzotto, G., and G. Costa. 1991. Kiwifruit pollination by wind and insects in Italy. New Zealand Journal of Crop and Horticultural Science 19:381-384. 
Tromp, J., A. Webster, and S. Wertheim (eds.). 2005. Fundamentals of Temperate Zone Tree Fruit Production. Backhuys Publishers, Leiden, The Netherlands.

Vasilakakis, M., K. Papadopoulos, and E. Papageorgiou. 1997. Factors affecting the fruit size of "Hayward" Kiwifruit. Acta Horticulturae 444:419-424.

Valenzuela, L., and A. Konig. 1991. Polinización del kiwi. Revista Frutícola 12:27-42.

Walinga, I., J. Van der Lee, J. Houba, W. Van Park, and I. Novosamsky. 1995. Plant Analysis Manual. Kluwer Academic Publishers. Dordrecht, The Netherlands. $253 \mathrm{p}$.

Wojcick, P., and M. Wojcick. 2003. Effects of boron fertilization on Conference pear tree vigor, nutrition, fruit yield and storability. Plant and Soil 256:413-421. 
